\title{
III. SOME QUESTIONS FOR REPUBLICANS
}

\author{
DON HERZOG \\ University of Michigan
}

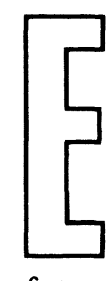

VEN A SLEEPY historiographer of political theory of some future day will notice the most dramatic revision of the last 25 years or so. I refer of course to the discovery-and celebration-of civic humanism. The devilish Machiavelli of Elizabethan times has been gently set aside for "the divine Machiavel," the one who writes, "I love my native city more than my soul."2 And historians of political thought have lovingly traced the transmission of civic humanism from Florence to England and America, giving us a brand new past. America, we now know, was not the unthinkingly Lockean land served up by Louis Hartz. ${ }^{3}$ Instead, our Founding Fathers - the phrase becomes more appropriate now-turn out to have been steeped in republicanism.

I do not doubt that this revisionist scholarship has been, on the whole, a good thing. But two features of it are troubling. First, there seem to be some generally unstated convictions about the links between the history of political thought and current political debate, links worth flushing out and assessing critically. Second, regardless of whether the links are valid, civic humanism is now regularly held up as an attractive alternative to liberalism; but humanists have advanced a remarkably hazy doctrine. To make their critique more penetrating, they need to answer some pressing questions, questions I will pose in a deliberately innocent way.

AUTHOR'S NOTE: My thanks to David Anderson, Mark Brandon, Shelley Burtt, Martha Feldman, Amy Gutmann, Isaac Kramnick, Arlene Saxonhouse, Kim Scheppele, Joel Schwartz, Bernie Yack, and the editor of this journal for comments on an earlier draft.

POLITICAL THEORY, Vol. 14 No. 3, August 1986 473-493

Q 1986 Sage Publications, Inc. 


\section{I}

Like other revisionist scholarship, the literature on civic humanism has been marked by an extraordinary and excessive zeal. Sometimes one suspects that the goal is to show that there never were any liberals, or that John Locke was the only one in world history. Donald Winch has managed to read even Adam Smith as a republican, by focusing on Smith's account of the militia. ${ }^{4}$ One can always quibble with such overstatements. So, for example, I would argue that Winch has missed a rather mischievous riposte from Smith to his dear friend David Hume, who managed occasionally to say nice things about militias. ${ }^{5}$ Smith thinks it is easy to show that militias are obsolete, that the changed military and political circumstances of modern society make it absurd to rely on them for national defense. He thus uses a Humean argument against Hume, beginning by launching into praise of militias and their place in restoring civic virtue, but closing by noting drily that, as it turns out, militias always lose to standing armies. ${ }^{6}$

It is of concern to Smith scholarship whether or not Winch gets Smith right on military matters. But it hardly matters in assessing the drift of humanist revisionism. We should expect and even desire a fair amount of overstatement, of judgments that can't possibly be sustained upon mature deliberation. Revisionists generally want to topple some received wisdom, and received wisdom tends to be unhappily ossified stuff. It may take excessive zeal to motivate an attack on it, and it may take excessive zeal to succeed in correcting its worst errors. ${ }^{7}$ The intellectual community should eventually straighten things out, and may find itself indebted to its most onesided members. (Objectivity thus depends not on saintly individuals with an austere regard for truth, but on free exchange among many individuals, all of whom may be biased.) So much is all too familiar from Mill; I merely suggest recalling his argument in the heat and fury of duels over footnotes.

But some of the zeal animating republican revisionism is not purely historiographical. It often seems that the goal is to show that civic humanism is a valuable possibility today. That goal is sometimes made explicit, sometimes hinted at. Quentin Skinner, in an illuminating reading of Machiavelli on freedom, says boldly, "I shall attempt to show ... that the Roman stoic way of thinking about political liberty is indeed the tradition we need above all to recapture if we wish to provide a corrective to the dogmatism about the topic of social freedom that marks both Hobbes' Leviathan and the writings of more recent theorists 


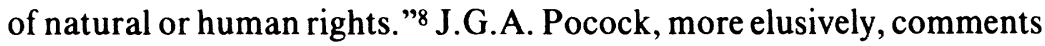
that "there are (if it matters) ideological reasons" for pursuing the history of civic humanism "in its own terms." And Michael Sandel declares that "If the 'republican school' is right about our ideological origins, then perhaps there is hope for revitalizing our public life and restoring a sense of community.... So the debate about the meaning of our past carries consequences for the debate about present political possibilities."10

Why should the historical presence or absence of some tradition have anything to do with today's political debates? I do not mean to suggest a global skepticism about studying the history of political theory. My point is more restricted: Suppose someone today wants to champion the cause of civic humanism. Why should he or she care whether or not people 200 (or 300 , or 400 ) years ago championed it too? Isn't it appropriate to let the dead rest in peace? Doesn't it smack of ancestorworship to think the cause is somehow legitimated by the discovery that it was prized long ago?

There are different ways to answer this question, some of them more sensible than others. Let me review the answers suggested by the three authors I mentioned above.

Skinner's goal is to articulate a conception of freedom that will meet a challenge posed squarely by Isaiah Berlin. He wants a notion that will surpass negative freedom, but without embracing any controversial Aristotelian assumptions about man's true end or highest nature. $\mathrm{He}$ needs, then, to tie freedom to activities like participation without claiming that human beings flourish most fully in participating. Skinner is surely capable of putting arguments in his own voice; he doesn't need to hide behind the capacious skirts of Machiavelli. As he notes, however, "it is apt to seem much less convincing to suggest that a concept might be coherently used in an unfamiliar way than to show that it has been put to unfamiliar but coherent uses." 11 It is one thing to sketch a defense of participation that links it only to ensuring the continued ability to pursue one's ends, whatever they are, another to explicate an existing and richly complex defense. Philosophers these days are likely to think of the discussion of Machiavelli as an intrusion, but Skinner's strategy seems quite sensible.

Pocock's goals are less obvious. J. H. Hexter has marveled at Pocock's ability to frame an encyclopedic account of modern political thought and resolutely avoid mentioning liberalism. ${ }^{12}$ One might wonder just what the point is of being quite so insistently devoted to 
resurrecting republicanism, or suspect that Pocock's tale is something like Rosencrantz and Guildenstern Are Dead-or perhaps Grendel. But Pocock has suggested a quite sensible goal in discussing The Machiavellian Moment, in referring to "critics of liberalism who maximize its role in order to provide themselves with an antithesis."13 Marxists and Straussians, he points out, are both committed to offering us a picture of modernity riveted on liberalism. If the present is fatally flawed by liberalism, one can then consider proffered alternatives to liberalism, whether some brave future socialism or some wistfully recalled Athens. Both modes of argument are, despite Strauss's pointed objections, historicist; both inescapably tie questions of historical development to evaluating our present possibilities. ${ }^{14}$ If modernity is in fact not benightedly liberal through and through, Marxist and Straussian polemics alike lose much of their force. For we don't face the awful predicament they summon up as their starting point.

Sandel's suggestion is the most ambitious of the three, and bears repetition: "If the 'republican school' is right about our ideological origins, then perhaps there is hope for revitalizing our public life and restoring a sense of community." This suggestion offers a more general reason for linking the history of republicanism with our own debates: One can embrace it without any care for the concept of liberty, without the slightest regard for the elaborate turns of Straussian and Marxist plaints against modernity. And, indeed, I think some view like Sandel's animates much republican revisionism; political theorists routinely offer interpretations of celebrated figures from the tradition to make political points today. Not many of us are really necrophiliacs, however we may strike our colleagues.

Still, Sandel's claim sounds at least like a non sequitur. What could his "if" clause possibly have to do with his "then" clause? First we have a historical question: Was civic humanism prominent in colonial America? Then we have a political question: Is civic humanism a valuable possibility for us today? These questions seem wholly independent; we need an explanation of why one should think that answering yes to the first makes it possible, or even easier, to answer yes to the second. Why shouldn't there be "hope for revitalizing our public life,"even if America always was the stolidly Lockean land summoned up by Hartz? The trivial verbal maneuver, that it can't be revitalized if it was never communally vital in the first place, is manifestly unsatisfactory. We can always rephrase the question: Why shouldn't there be hope for vitalizing our public life for the first time? Those sympathetic to republicanism 
know full well the mystique of magical foundings; instead of bringing our corrupt regime back to the first principles from which it has so sadly fallen, why can't we create a republican regime for the first time? Why can't we earn the praise Machiavelli lavishes on founders?

Perhaps we can. But we should proceed carefully; although there is some gap between the historical question and the political one, it may be impetuous to conclude that they are wholly independent. Let me sketch three accounts of how we might connect them.

Consider first the possibility of exploiting some puzzles in the philosophy of history. Difficult as it is to offer any straightforward account of how some historical outcome was caused, we might play on an equivocation in the claim that some event or tradition was prominent. A skeptic might urge that we can never know how causally efficacious it was. Replication is impossible; cross-cultural data for comparative historical sociology always pose contentious questions of interpretation; and we have no social theory like classical mechanics, offering firm and readily validated accounts of causal triggers. So, the skeptic might continue, talk of prominence in fact always lapses into evaluative questions, even when parties to a dispute would strenuously deny it. Deciding whether republicanism was prominent in the colonies isn't simply a matter of toting up the numbers to see how many individuals were republicans. Nor can it be a matter of figuring out how much of a difference republicanism made, because again we have no way of grounding any claims about causation or counterfactuals. So it must really be a matter of arguing about how valuable republicanism is.

Any such account would indeed tie historical questions to today's political ones. But it would do so too easily, simply by transforming the former into the latter. In this view, sometimes we argue about our politics by talking about Reagan; sometimes we argue about our politics by talking about Franklin; but we are always arguing about our politics. A sweep through the sociology of knowledge may make such a view look bleakly plausible, too. I have no facile refutation up my sleeve, no lucid account of how we can sensibly discuss causation in history. But republican revisionists would shrink from the suggestion that all they are doing is masking our political arguments in centuries-old disguise. Writers like Pocock and Gordon Wood are, after all, enormously talented historians.

Consider second, then, what we might call the icon approach. Many tend to revere august figures from the history of political thought. We may all have our own favorites and enemies-Nietzsche, for instance, is 
frequently embraced, just as frequently excoriated-but one set of favorites is widely shared in America. They are the Founders, caught up in an extraordinary process of mythmaking from the time of the Revolution. The Supreme Court frequently defers to the intentions of the Founders, or at least claims to. Television commentators grace their arguments with obligatory bows in their direction. Even college students, not usually the most reverential crowd, expect and desire plenty of laudatory comments on the Founders in classes on American political thought.

We may disapprove of this sort of thing. However impressive Franklin or Jefferson may be, we may think that clouding over their achievements with a loving haze can only detract from responsible political argument. Like it or not, though, the haze is now there, and it serves an ideological function. For if we tend unthinkingly to embrace liberalism, and we revere the Founders and think of them as liberals, our liberal tendencies will only be reinforced, and we will look askance at any daring to advance critiques of liberalism.

To open up debate, then, to force people to confront issues more rationally, it may help to smash some icons. Historians may not simply be gossiping when they tell us that Jefferson had an affair with his slave, Sally Hemings. ${ }^{15}$ Nor need we restrict our attention to allegedly unsavory biographical facts; more intellectual modes of attack are available. Alasdair MacIntyre, for example, makes Aristotle the spearhead of his recent assault on liberal society, and astonishingly reads Aristotle as oblivious to political conflict. ${ }^{16}$ It then becomes tempting to smash MacIntyre's icon, or turn his spearhead against him. And so it becomes satisfying to discover that Aristotle says nothing like what MacIntyre attributes to him. ${ }^{17}$

Reinterpretations of the Founders can play a similar ideological role. The goal may be to transfer unthinking allegiance from liberalism to republicanism. Or, if our commitments to the Founders aren't that overwhelming, the goal may be to deliver a bracing slap and force us to confront an indictment of liberalism, instead of murmuring endlessly on the brilliance of Madison. Our ideological attachments to great figures in political thought thus tie the history of theory to present political debates. Civic humanists can hardly be blamed for playing the game as it stands.

Revisionists, though, might wish to deny that their scholarship should be placed in so crassly ideological a context. They might offer a more ambitious attempt to link our history with our present. 
Consider third, then, what we might call the "past is present" approach. Suppose that any adequate account of our present will inescapably be historical, that any desire to "forget all that historical stuff" and offer a political-science analysis of the present is systematically misconceived. If the present is always archaeological in this way, if our cultural past endures as stubbornly as Freud thought our childhood experiences do, then it matters whether the past was republican. For if it was, then perhaps the present still is. Or, more accurately, then perhaps the present could be, if we reclaimed the dormant but still present past. Such a view would offer strong support for the claim that revisionist history is directly relevant to our political debates. But can such a view be worked out adequately here?

Take an easy case first, one premised on nothing more grandiose than individual memory. Americans now are sensitive to the possibility of repeating Vietnam. They disagree, of course, about how to interpret Vietnam, or what a sad repetition would amount to: Would it be allowing ourselves to be stuck in a quagmire? Or would it be allowing our political will to be sapped by unconscionable domestic opposition? Regardless, any adequate account of today's foreign policy debates would have to refer to (competing accounts of) Vietnam. Generally, in such cases it seems sensible to say that any account of our present must include some of our past. Republican revisionists, however, cannot exploit such cases. They are not reminding us that we, people alive now, were ardent civic humanists ten or twenty years ago. So they can hardly appeal to psychological memory.

Memory, though, might be reconceived in more sociological terms. There are straightforward senses in which cultures have memories. Social practices may endure past the settings in which they arose as plausible solutions to contingent conflicts. Adam Smith, for instance, argued that Englishmen in 1776 continued to cling to primogeniture, even though its justification - namely, keeping land lots large enough to repel attacks from barbarians or threatening neighbors-no longer applied. ${ }^{18}$ Anthropologists often suggest that today's natives carry on versions, sometimes badly distorted versions at that, of rituals that were richly meaningful generations before, but with no sense of how they could be meaningful. Such examples provide a nonmysterious rendition of Durkheim's social facts, which here are "outside" individuals without our conjuring up some Casper the Social Ghost. Republican revisionists, though, cannot exploit these cases either. They are not suggesting that we continue to cling to republican practices without understanding their 
underlying justification or meaning. Indeed, it must be part of their case that we have jettisoned our republican past, that its practices have evaporated. After all, we happily accepted Hartz's portrait of a Lockean America for some time; republicanism needed to be recovered with painstaking historical care, not just pointed to.

Another sort of social fact-language-might seem to provide a helpful key. Pocock himself has shown how a language may endure over time, enabling ideas to be transmitted without individuals consciously striving to transmit them. And Charles Taylor has argued that our language does much more than allow us to swap propositions: In its expressive dimension it is partly constitutive of our social practices and our personal identities. ${ }^{19}$ The language of common good does indeed survive in America; sadly or predictably, it is an obligingly pliable pretext, at the beck and call of politicians of all stripes. Now, that strand of our self-image wrapped up in community may be withering and under fire for all sorts of reasons. We can round up the usual suspects, indicted endlessly ever since the French Revolution: mechanist views of science and the social sciences, atomistic conceptions of presocial individuals, negative images of freedom suggesting that attachments to others involve a loss of autonomy, bureaucratic or technocratic accounts of rationality, and the social practices animated by such views. ${ }^{20}$ But surely, a republican might urge, it is an open question whether or not our politics will succumb further to such onslaughts.

There are two ways of interpreting this case. Sometimes it is thought that rejecting mechanism, atomism, and the rest must entail rejecting liberalism. But liberalism is a tradition, not a single view, and like any other tradition it is best conceived of as a family of disagreements. Granted, Hobbes and Locke may seem to insist on instrumental rationality, presocial individuals, and so on; but it hardly follows that those positions are integral to liberalism. We need not even flee the Anglo-American tradition and appeal to the likes of Aristotle and Hegel to find critiques of such views. Adam Smith is fascinated by what we would call the social construction of personal identity, and his Theory of Moral Sentiments develops an elaborate account of the role of reflexivity; David Hume scoffs at the myth of presocial individuals; John Stuart Mill places self-development squarely at the heart of his political theory: But all are liberals.

Second, it might be agreed that liberals can reject mechanism, atomism, and the rest. But richer views of language and agency might still provide the desired connection between past theories and present 
possibilities. Hidden away in our language, and so potentially in our social lives, are the concepts and categories of republicanism. But here we must beware two conflations. Human society may rest on "a high degree of inter-subjective meanings," but "this can go along with profound cleavage": Only those who fully understand one another can fully loathe one another; ${ }^{21}$ tout comprendre, c'est tout détester. And it is always an open question whether our implicitly republican vocabulary furnishes an adequate interpretation of the world: Thinking the world is congenial to republicanism doesn't make it so; no agent's beliefs about his society are incorrigible. ${ }^{22}$ So language seems insufficient on its own: If our language and our practices mutually supported one another, republicans would have a case. But if only our language still echoes with republicanism, our self-image as republicans invites exposure as mere nostalgia, or a quixotic hangover. For these reasons, I don't see how language alone could furnish the relevant connections between our history and our present politics.

In what other sense might the past endure? Are the posited continuities between our republican ancestors and us purely geographical? Geography surely does not suffice to establish any cultural continuities. Glaciers once crossed the United States, too, but that hardly shows we can "recapture" our glacial past. Does it matter that here, right here in America, people were virtuous citizens, or thought others should be? With neither a psychological nor a sociological sense in which the past endures, what is the point of appealing to a specifically American past? Would anything be lost if republicans appealed to events in sixteenth-century Florence?

My purpose in raising such possibilities is emphatically not to suggest that there are no interesting ties between our history and our present. It is instead to give a sense of the alarmingly different interpretations of that claim we can offer. Many writers working today in the history of civic humanism assert or imply some connection between that history and our political debates today. They need to articulate precisely what sort of connection they have in mind; otherwise, our discussions will flounder.

\section{II}

Those championing republicanism, virtue, and community today also need to explain in some more detail than they have just what sort of 
politics they are offering. Too much time has been spent assaulting liberalism, too little articulating and defending an alternative in any detail. ${ }^{23}$ Sometimes the gap between indictment and remedy is simply laughable. Thus George Will, in his "complaint against the modern world," summons up apocalyptic visions of our desperate predicament. When it comes to solutions, though, Will calls vaguely-and troublingly - for a politics that "can be thrilling and noble," or tells us that "A nation offers limitless scope for moral explorations." 24 (He does propose tightening up pornography laws, but that solution seems incongruously trivial, given the gloom-and-doom portrait he offers of our problems.)

It is, of course, a far cry from Will's jeremiad to some of our more sober scholarly debates. But the same intimations of impending disaster haunt the latter, and they are all too often vague in the same way. By leaving their central concepts unhappily vague or abstract, republican theorists make their case inviting to those already inclined to agree, unconvincing to those inclined to disagree-and just plain confusing to those of us without any marked inclinations at all. Here is one striking parallel between historical and political issues: Neither can be pursued profitably without a focused vocabulary. So I mean now to raise some questions to which republicans owe us answers. My comments here are critical, sometimes sharply so. But they are not refutations: We rarely if ever find those in political theory. Instead they are invitations to republicans to make their position more articulate than they have so far.

To talk about the political merits of republicanism today, I will discuss some historical figures. My own use of history here falls under two of the possibilities I canvassed above. Like Skinner, I want to underline the claim that some view is possible by showing that it was actually embraced; I do not want to be accused, that is, of dreaming up fantastic possibilities. I also want to employ an inversion of the icon strategy, by supplying an unsavory figurehead-Benjamin Rush-for the republican cause. And, finally, I shall offer some brief comments on Machiavelli's History of Florence, comments intended to suggest that the fount of modern republicanism not only confronted some problems with republicanism, but offered remedies that one might be tempted to call liberal in spirit.

One Founder who has received more than his share of attention from republicans is Thomas Jefferson. Pocock says that Jefferson is "as committed as any classical republican to the ideal of virtue." 25 We are used to thinking of Jefferson in terms of yeoman farmers and the like, 
and it would be foolish to deny that he sometimes adopts the language of civic humanism. He can celebrate farmers as "the most valuable citizens ... the most vigorous, the most independent, the most virtuous," and he can juxtapose republican "vigour" and "degeneracy." 26 But it would be hasty to infer that the mere appearance of such words shows that Jefferson is best conceived of as a republican. We need to explore just what use he puts them to in his writings, to ask if his usage perhaps precludes lumping him together with the likes of Machiavelli or Harrington.

Indeed, it is misleading to cast Jefferson as a republican. Joyce Appleby has ably argued that much of our image of Jeffersonincluding that of the yeoman farmer-simply finds no support in his writings. ${ }^{27}$ More important, Jefferson's commitments do more than introduce Harringtonian modifications into classical republicanism;28 they drive him outside that tradition. Three points are worth noting. First, Pocock rightly notes that Venice "became a myth, exercising compulsive force on the imagination" in the civic humanist tradition. ${ }^{29}$ But then Jefferson's blunt rejection of Venice-“173 despots would surely be as oppressive as one. Let those who doubt it turn their eyes on the republic of Venice" ${ }^{30}$ - speaks symbolic volumes. Second, Jefferson's enthusiastic fight for religious toleration hardly fits well with the view, so central in say Machiavelli's thought, that religion can be a wonderful tool for political socialization. Third, Jefferson was happy to distance himself from the claim that talented individuals owe their lives to their country. Even in private letters, Jefferson never could have claimed proudly to love his country more than himself. Instead, he somewhat sourly insisted that individuals may live their own lives: "It were contrary to feeling and indeed ridiculous to suppose a man had less right in himself than one of his neighbors or all of them put together. This would be slavery." ${ }^{11}$ These views help make Jefferson attractive, at least to those of us fond of liberalism. They also make him an unlikely model for communitarian critics of liberalism.

A more likely model is Benjamin Rush (1746-1813), Professor of Medicine at the University of Pennsylvania, Physician General for Washington's army, prolific writer on medical, political, and educational issues, friend of more famous Founders, and himself a signer of the Declaration. Rush is best known for a paper presented to the American Philosophical Society in 1799. In his "Observations Intended to Favour a Supposition that the Black Color (As It Is Called) of the Negroes is Derived from the Leprosy," Rush argued that the woolly hair, flattened 
nose, broad lips, and superhuman sexuality of blacks arises from a curious kind of leprosy. This he took to be a compassionate point, since it meant that blacks were entitled to solicitous care, not abuse. Rush also took it to be a politically significant point. Like other colonial republicans, he worried that a racially heterogeneous community might never become a politically unified one. If blacks were diseased, though, they might be cured. Rush speculated that nature might be spontaneously curing blacks (so he interpreted some cases of albinism), and added that we might be able to accelerate nature's cure by applying pressure to the skin, or perhaps unripe peach juice. ${ }^{32}$

It would be easy - too easy - to dismiss this as yet another example of how ideology affects the practice of science. It is that, but, more important, it also poses a political question for republicans. Suppose, as is manifestly true, that we now live in a society hardly unified by a shared understanding of the common good, hardly peopled by virtuous citizens always willing to renounce their partial claims in the interests of the whole community. We then face a transition problem: What means shall we employ for forging (or "recovering") a republican politics? It would be amusingly ahistorical to suggest that we have no choice but to start "curing" blacks, or to embrace Jacobin terror. Yet there are less anachronistic but equally disturbing options: We might move to quash gay rights, or keep women in traditional roles, thinking that the increased freedom of either group threatens social order and community. These options are unpleasant, no doubt; but we need a theoretical account of why we should resist them. Today's republicans owe us an account of how we are to build a politics of civic virtue in the United States, among citizens "entangled in a network of obligations and involvements unassociated with any act of will, and yet unmediated by those common identifications or expansive self-definitions that would make them tolerable." 33 To put the point succinctly, if liberalism is the problem, how could republicanism be the solution?

Education, broadly conceived, may seem to some the answer to this question. Our identities aren't set in concrete; with new experiences, we may come to reconceive ourselves, to become the sorts of citizens republican politics demands that we be. Education, though, can mean many different things. The mere word cannot provide an answer to the transition problem. And some modes of education may be repugnant.

Consider again Rush. Rush was dead set against the religious toleration urged by Jefferson. He was charmed by the "moral order" he observed in Edinburgh, with "churches ... filled on Sundays," packs of 
cards nowhere to be found, little swearing or drunkenness, and more, a lovely state of affairs he attributed to "the parochial instructions of the clergy." 34 Rush was happy to generalize from his visit to Edinburgh. In 1791, he urged the universal adoption of the Bible as a school book. Assuming "that Christianity is the only true and perfect religion, and that in proportion as mankind adopt its principles, and obey its precepts, they will be wise, and happy," Rush lamented America's failure to adopt "the only means of establishing and perpetuating our republican forms of government, that is, the universal education of our youth in the principles of Christianity, by means of the Bible." 35 In 1798, he set out a more general view of education. ${ }^{36}$ Aspiring to imitate the Spartans, Rush rejected the grand tour, or any kind of education abroad. Americans, he thought, were too diverse already; pluralism is the enemy of "uniform and peaceable government." Rush again urged the adoption of Christianity, neatly articulating the structure of his republicanism: "without [religion] there can be no virtue, and without virtue there can be no liberty, and liberty is the object and life of all republican governments." The New Testament would serve best, since "a Christian cannot fail of being a republican." (The transmission of civic humanism from Florence to America here resembles the game of telephone, where the message is systematically garbled.)

Rush's education (if successful) would produce not just morally upright citizens, but politically devoted ones. Here Rush set himself against Jefferson's claim that one is entitled to live for oneself. (In an ambivalent sketch of Jefferson, Rush reports that when he asked Jefferson if he would be willing to go to France as a Commissioner, Jefferson "said "he would go to hell to serve his country'"- but he adds that when elected, Jefferson "declined at that time on account of the sickness of his wife." ${ }^{37}$ ) Rush's Christian student would indeed be a zealous republican: "Our country includes family, friends and property, and should be preferred to them all. Let our pupil be taught that he does not belong to himself, but that he is public property." Yet it would be unrealistic, added Rush in a sudden moment of xenophobic sobriety, to expect students "to embrace, with equal affection, the whole family of mankind," so they may prefer citizens of the United States. Rush's student would also learn correct political theory_- "He must be taught that there can be no durable liberty but in a republic"-and wash it down with Sparta's black broth. Even the golden age, concluded Rush, could be no more delightful than the world the Pennsylvania legislature could create by adopting his educational program. 
Religious and political indoctrination, then, is one possible approach to education. Given Rush's arguments, one might wonder if there are deep similarities between civic humanists in the academy and the Moral Majority. One might wonder more generally if the republican tradition has an element of hostility to individualism itself, if virtuous citizens are unpleasantly like robots. Rush pulls no punches, but staunchly affirms that "it is plain, that I consider it is possible to convert men into republican machines," machines who would unhesitatingly affirm that "Every man in a republic is public property. His time and talents-his youth-his manhood-his old age - nay more, life, all, belong to his country." 38

Dismissing Rush as a lunatic republican, an eccentric representative of the tradition, will not do. For one thing, we need again an account of why this sort of thing is lunatic; for another, it simply isn't eccentric. It was Rousseau who insisted that good citizens are too stupid to be fooled by clever arguments, ${ }^{39}$ that good education will "choke off vices before they are born," that "The newly-born infant, upon first opening his eyes, must gaze upon the fatherland, and until his dying day should behold nothing else." ${ }^{40}$ Robots do not make creative citizens, but the republican tradition tends to attribute political creativity exclusively to the great legislator who shapes society. Republican citizens "participate," but only to reinforce their socialization. That is why, however weird it might seem from the standpoint of democratic theory, Rousseau's citizens are not supposed to talk too much in exercising their sovereignty. ${ }^{41}$ And that is why the citizens of Harrington's Oceana worship Cromwell; one citizen breaks down with "tears of joy" in obsequiously celebrating the Lord Archon (Cromwell's transparent disguise in the work):

\begin{abstract}
Ah, my Lord Archon shall walk the streets (as it be for his ease I mean) with a switch, while the people run after him, and pray for him; he shall not wet his foot, they will strew flowers in his way; he shall sit higher in their hearts, and in the judgment of all good men, than the kings that go up stairs unto their seats, and one of these had as good pull two or three of his fellows out of the great chairs as wrong him or meddle with him; he has two or three hundred thousand men that, when you say the word, shall sell themselves unto their shirts for him and die at his feot. ${ }^{42}$
\end{abstract}

These are graphic and repellent images of just what one can accomplish-or hope to-in educating virtuous citizens.

Even a proposed strategy for transition as seemingly innocent as education, then, may be worrisome. Again, if republican politics are to be seriously offered as a live option for us today, we need some story 
about how we might realize the considerable requisite social and psychological transformations. But there are at least two more problems for republicans besides the transition problem: specifying a consensus and dealing with conflict.

Like their forebears, today's civic humanists long for a world in which people share fundamental projects. Looking at our liberal pluralist society, they see chaos instead of a harmoniously ordered community in which some shared telos allows us to resolve our disagreements. ${ }^{43} \mathrm{~A}$ diagnosis of chaos may depend on viewing the world through the lens of Aristotelian or Durkheimian social theory, not on any actual problem in the world. ${ }^{44}$ We have no good reason, that is, to think that fundamental moral consensus is what it takes to hold society together. Be that as it may, republicans also owe us an account of what commitments should bind us, what content the communal attachments that should transcend our individual projects should have, what exactly the common good should be.

Critics of liberalism are fond of charging liberalism with being perniciously incomplete. Liberals, they tell us, refuse to hold up any authoritative conception of the good life; liberals think that all that matters is survival, or the gratification of appetites. Liberals have an easy rejoinder: Politics is now one social setting among many, so individuals can pursue the good life in other social settings. To say that politics shouldn't be about the good life isn't to say that the good life doesn't matter. The accusation seems better directed against republicans. That we should share commitments may sound inviting; it might be nice to live in a community with others who shared your deepest commitments, especially if you could play on game-theoretic, many-leveled knowledge (you know they agree, they know you agree, you know they know. . .). But which commitments should we share?

Rush's answer, that we should share Christianity and moral order, is not likely to appeal to civic humanists in the academy, whatever its appeal outside the academy. Naming any conception of the common good would of course reinforce the transition problem: Once the conception is on the table, it will seem even more implausible that we could lead everyone to agree on it-whatever the conception is.

Maybe republicans should try to sidestep the question, by adopting a procedural account of how we will specify what the common good is: by democratic debate. Celebrations of democracy are doubtless not the same as those of civic virtue, but they may meet here. ${ }^{45}$ Once again, though, we need to hear more. Will the debate be direct or representa- 
tive? Will it be decentralized or national? Communitarians are often suspicious of representative democracy, which they are inclined to denigrate as a pallid liberal caricature of real democracy ${ }^{46}$ And the tradition tells us that republican fervor is easier to sustain in local settings. But how many of us would like to be living in the deep South when the people assemble to vote on what the common good is?

Whether they plump for representation or direct self-rule, for a national politics or a local one, republicans might point out that we often think of democratic debate as yielding a consensus. Sometimes, though, that consensus is better understood as an uneasy compromise, subject to constant renegotiation, than as genuine agreement. And sometimes democratic politics yields no consensus at all; even such garden-variety settings as school board politics can be enduringly divisive. Surely it strains credibility to suggest that public debate over the common good, over what fundamental projects citizens should share, would yield any real consensus. And surely if it did, we would have to worry that a lack of vigorous disagreement would make democratic debate less intelligent than it would otherwise be. Deepseated disagreements need not be deplored as a sign of the fragility of community in modern society; they can be embraced as integral to full-blooded debate. And democratic citizens can agree that vigorous debate is a good thing without agreeing on conceptions of the good life. Liberals generally may agree that we do have a shared interest in upholding liberal democratic institutions. But any such account of the common good, leaving us free to frame wildly conflicting life plans, would not satisfy our republicans.

Ironically, today's republicans may be more confident of the possibilities of attaining consensus than their intellectual ancestors. So it becomes tempting - here's the icon strategy again - to set Machiavelli against our republicans. Machiavelli has been accused of dreaming, of uncritically echoing stale Roman platitudes on the common good. ${ }^{47}$ The charge is probably unfair to Roman political thought: In a shrewd piece of debunking (and the first real piece of behaviorism I know), Polybius exposes the famed civic virtue that makes Roman soldiers so valiant as nothing but the effects of a carefully designed scheme of rewards and punishments on rational agents. ${ }^{48}$ The charge is surely unfair to Machiavelli, whose community of civic virtue is conflict-ridden.

In fact, Machiavelli insists that "those who believe republics can be united are greatly deceived in their belief." 49 The relevant text here is Machiavelli's History of Florence; for those not captivated by Machia- 
velli's claims that everything he knows is in the Prince and the Discourses, the History is decidedly interesting, clarifying the Discourses' waves toward a politics of the common good. Guelf against Ghibelline, Bianca against Nera, nobles against middle class, Buondelmonti against Uberti, Donati against Cerchi, Albizzi against Ricci: The list of Florentine conflict stretches on and on. Although Machiavelli wants to ridicule Florence's failure even to approach the grandeur of Rome, the stubborn endurance of such conflict does not itself rule out Florence's claim to be a republic. Unity may even be the enemy of republican liberty. When the Duke of Athens took control of Florence, "he said it was not his purpose to take away the city's liberty, but to give it back again, because only disunited cities were slaves and united ones free." Yet Machiavelli disapproves: The Duke had a "hardened mind" in rejecting the Signors' plea that he content himself with freely given, partial authority, and his installment in the Palace "took place to the incredible sorrow and afflictions of good men, and to the great pleasure of those who through either ignorance or malice agreed to it." 50

The Duke's rule was harsh, marked by heavy taxes, unjust judgments, cruelty, murder, torture, exploitation, the importation of French customs, and rapes. His rule epitomizes a point Machiavelli tirelessly repeats in the History: A politics of the common good relying on a single individual is fragile. 51 Should the individual be weak, greedy, or passionate, he may harm the whole city. Republican self-government, with less concentration of power, has less potential for abuse.

But again, there is no question that there will still be pointed disagreement. In Machiavelli's view, both Rome and Florence were disunited. The differences lay in how acrimonious the disputes were and how they were handled. Where Rome debated, Florence fought; Rome legislated, Florence exiled and killed; Rome boosted her military strength, Florence "wholly destroyed" hers; and-intriguingly for egalitarian republicans-Rome was left with greater inequality, Florence greater equality. ${ }^{52}$

How, then, does Machiavelli propose to deal with conflict? In a way strikingly reminiscent of Bentham and Madison, writers not ordinarily thought of as his intellectual bedfellows. The Machiavellian legislator tries to ensure that the pursuit of private interest will pay off in public benefits, and even has "selfishly ambitious men ... watch each other in order that lawful bounds may not be overpassed." $\$ 3$

I have no desire to enlist Machiavelli as a closet liberal, no desire to suggest that any thoughtful remedies for political conflict will lead in 
liberal directions. Instead, I want to point out that liberalism would provide resources for answering all the questions I've raised about republican politics. Thinking of individuals as having rights, thinking of those rights as shields enabling individuals to pursue their own plans, would eliminate troubling solutions to the transition problem. We could not entertain coercion, for it would violate rights. Casting education as a way of helping individuals make informed choices would rule out any schemes hanging on turning individuals into machines. Embracing a theory of liberal democracy would rule out unconstrained majority rule. ${ }^{54}$ Employing a host of constitutional, legal, and institutional safeguards against the abusive exercise of political power would give us sensible ways of moderating political conflict - as would keeping such explosive subjects as conceptions of the good off the political agenda in the first place.

Today's republicans, though, do not want to draw on such familiar liberal strategies. They want republicanism to be an alternative to liberalism. No one would deny, however, that there are characteristic dilemmas arising in the tradition of civic virtue (just as there are in other traditions). Does the tradition boast adequate resources to deal with its own problems? Are there principled republican explanations of why the noxious possibilities summoned up by the likes of Rush represent bad republicanism? Or must republicans always covertly draw on liberal principles?

I suggested earlier that if liberalism is the problem, it is hard to see how republicanism could be the solution. Some may want to invert the point, and say that republicanism is the problem, liberalism the solution. I am not (yet) willing to adopt that claim, and surely have not defended it here. Instead, I have raised some pressing questions for republicans, questions I hope will focus and deepen our political debate. We can only gain from attempts to answer these questions: A more focused debate can reveal if republicanism is a vibrant remedy for the ills of liberalism, an incurably vacuous collection of sentimental slogans, or an alluring but destructive siren's song.

NOTES

1. Henry Neville, "Plato Redivivus," in Caroline Robbins, ed., Two English Republican Tracts (Cambridge: Cambridge University Press, 1969), 81. 
2. Machiavelli to Francesco Vettori, 16 apr 1527, quoted from Machiavelli: The Chief Works and Others, trans. Allan Gilbert, 3 vols. (Durham, NC: Duke University Press, 1965), II: 1010.

3. Louis Hartz, The Liberal Tradition In America (New York: Harcourt, Brace, 1955).

4. Donald Winch, Adam Smith's Politics (Cambridge: Cambridge University Press, 1979).

5. Duncan Forbes, Hume's Philosophical Politics (Cambridge: Cambridge University Press, 1975), 211-212, offers a good succinct sketch with references.

6. Adam Smith, An Inquiry into the Nature and Causes of the Wealth of Nations, ed. R. H. Campbell, A. S. Skinner, and W. B. Todd, 2 vols. (Indianapolis: LibertyClassics, 1981), II: 589-708.

7. Consider Isaac Kramnick's incisive "Republican Revisionism Revisited," American Historical Review 87 (June 1982), 629-664, and J.G.A. Pocock's heated response, in the closing section of his Virtue, Commerce, and History (Cambridge: Cambridge University Press, 1985).

8. Skinner, "The Idea of Negative Liberty," in Richard Rorty, J. B. Schneewind, and Quentin Skinner, eds., Philosophy in History (Cambridge: Cambridge University Press, 1984), 204.

9. Pocock, "The Machiavellian Moment Revisited: A Study in History and Ideology," Journal of Modern History 53 (March 1981), 72.

10. Sandel, "The State and the Soul," New Republic (June 10, 1985), 39-40.

11. Skinner, "The Idea of Negative Liberty," 198.

12. Hexter, "Republic, Virtue, Liberty, and the Political Universe of J.G.A. Pocock," in his On Historians (Cambridge: Harvard University Press, 1979), 293-303.

13. Pocock, "Machiavellian Moment Revisited," 70.

14. For Strauss's attack on "historicism," see his Natural Right and History (Chicago: University of Chicago Press, 1953), 9-34. For the similarities between Marxists and Straussians, consider Strauss's favorable review of C. B. Macpherson, The Political Theory of Possessive Individualism (Oxford: Clarendon, 1962), in his Studies in Platonic Political Philosophy (Chicago: University of Chicago Press, 1983), 229-231, especially the closing.

15. Fawn Brodie, Thomas Jefferson (New York: Norton, 1974); Ronald T. Takaki, Iron Cages (New York: Alfred A. Knopf, 1979), 50-55, intelligently discusses the contemporary political significance of such charges.

16. Alasdair MacIntyre, After Virtue (Notre Dame, IN: University of Notre Dame Press, 1981), 146-147, 153; or After Virtue, 2d ed. (Notre Dame, IN: University of Notre Dame Press, 1984), 155-157, 163-164.

17. See Bernard Yack, "Community and Conflict in Aristotle's Political Philosophy," The Review of Politics 47 (January 1985), 92-112.

18. Smith, Wealth of Nations, I: 381-384.

19. See particularly Taylor, "Language and Human Nature," in his Human Agency and Language (Cambridge: Cambridge University Press, 1985); although this thread is woven through much of Taylor's work.

20. See the essays in the second part of Charles Taylor, Philosophy and the Human Sciences (Cambridge: Cambridge University Press, 1985), and MacIntyre's After Virtue. 
21. Taylor, "Interpretation and the Sciences of Man," in Philosophy and the Human Sciences, 36.

22. Taylor, "Social Theory as Practice," in Philosophy and the Human Sciences, 101; Taylor, "Understanding and Ethnocentricity," in Philosophy, 123-124.

23. As for example in Michael Sandel, Liberalism and the Limits of Justice (Cambridge: Cambridge University Press, 1982).

24. Will, Statecraft as Soulcraft (New York: Simon \& Schuster, 1983), 141, 140, 138.

25. J.G.A. Pocock, The Machiavellian Moment (Princeton, NJ: Princeton University Press, 1975), 533.

26. Thomas Jefferson to John Jay, 23 aug 1785, in The Portable Thomas Jefferson, ed. Merrill D. Peterson (Harmondsworth: Penguin, 1983), 384; Notes on the State of Virginia, Query 19, in Portable, 217.

27. Joyce Appleby, "Commercial Farming and the 'Agrarian Myth' in the Early Republic," Journal of American History 68 (March 1982), 833-849; see too her "What is Still American in the Political Philosophy of Thomas Jefferson?" William and Mary Quarterly, 3d ser., 39 (April 1982), 287-309.

28. Compare Pocock, Machiavellian Moment, 533-541.

29. Ibid., 102.

30. Jefferson, Notes on Virginia, Query 13, in Portable, 164.

31. Jefferson to James Monroe, 20 may 1782, in Portable, 365.

32. For discussions, see Winthrop D. Jordan, White Over Black (Chapel Hill: University of North Carolina Press, 1968), 495, 517-522; Takaki, Iron Cages, 30-34.

33. Michael J. Sandel, "The Procedural Republic and the Unencumbered Self," Political Theory 12 (February 1984), 94. Consider too Michael Walzer's description of modern society in "Socialism and Self-Restraint," in his Radical Principles (New York: Basic Books, 1980), and Charles Taylor's "Legitimation Crisis?" in his Philosophy and the Human Sciences.

34. The Autobiography of Benjamin Rush, ed. George W. Corner (Princeton, NJ: Princeton University Press, 1948), 51-52.

35. Rush, "The Bible as a School Book," in The Selected Writings of Benjamin Rush, ed. Dagobert D. Runes (New York: Philosophical Library, 1947), 117, 130.

36. Rush, "Of the Mode of Education Proper in a Republic," in Writings, 87-96. The remaining quotations in this paragraph and those not otherwise cited in the next one are from this essay.

37. Rush, Autobiography, 151.

38. Rush, "Of the Mode of Education Proper in a Republic," in Writings, 92; Rush, "On the Defects of the Confederation," in Writings, 31.

39. Du contrat social, bk. IV, chap. 1 .

40. Jean-Jacques Rousseau, The Government of Poland, trans. Willmoore Kendall (Indianapolis: Bobbs-Merrill, 1972), 21, 19.

41. Du contrat social, bk. IV, chap. 2 .

42. The Political Works of James Harrington, ed. J.G.A. Pocock (Cambridge: Cambridge University Press, 1977), 349.

43. MacIntyre repeatedly insists that we need "a conception of the good" (his emphasis) to understand our own lives and to make defensible decisions: After Virtue, 204; After Virtue, 2d ed., 219. 
44. See here Niklas Luhmann, The Differentiation of Society, trans. Stephen Holmes and Charles Larmore (New York: Columbia University Press, 1982), especially the translators' introduction, $\mathrm{xv}$-xix.

45. For two recent works applauding democracy, see Joshua Cohen and Joel Rogers, On Democracy (Harmondsworth: Penguin, 1983); Benjamin Barber, Strong Democracy (Berkeley: University of California Press, 1984).

46. For a flirtation with the miracles of modern technology, see Robert Paul Wolff's discussion of direct democracy in his In Defense of Anarchism (New York: Harper \& Row, 1976), 34-37. It is no accident that this book follows on the heels of Wolff's The Poverty of Liberalism (Boston: Beacon Press, 1968).

47. Mark Hulliung, Citizen Machiavelli (Princeton, NJ: Princeton University Press, 1983), chap. 5.

48. Polybius, The Rise of the Roman Empire, trans. Ian Scott-Kilvert (Harmondsworth: Penguin, 1979), bk. 6, 318-338, especially 329-335. Note Machiavelli, The Art of War, bk. 6, in Chief Works, II: 689-690.

49. Machiavelli, History of Florence, bk. 7, chap. 1, in Chief Works, III: 1336. See too History, bk. 2, chap. 12, in Chief Works, III: 1093-1094.

50. Machiavelli, History of Florence, bk. 2, chaps. 34-35, in Chief Works, III: 11231126. Note Discourses, bk. 1, chap. 4, for explicit praise of dissension.

51. Machiavelli, History of Florence, bk. 4, chap. 1; bk. 3, chap. 17; bk. 3, chap. 25; bk. 7, chap. 4; in Chief Works, III: 1187, 1168, 1180-1181, 1340.

52. Machiavelli, History of Florence, bk. 3, chap. 1, in Chief Works, III: 1140. See too History, bk. 2, chaps. 25, 36, in Chief Works, III: 1110,1128 . The comment on equality is puzzling in light of Discourses, bk. 1, chap. 55. In any case, Machiavelli is not here prepared to dismiss Florentines' commitments to participation. Compare J. R. Hale, Florence and the Medici (Thames and Hudson, 1977), 90: under the constitution of 1494, "it was clear that large numbers of qualified citizens did not want to attend council meetings which consumed time many could ill spare from shop or counting-house. Others who wished to attend could not because their taxes were in arrears. A quorum was set at 1,000 and it was often difficult to raise one in spite of heavy fines for non-attendance."

53. Machiavelli, History of Florence, bk. 7, chap. 1, in Chief Works, III: 1337.

54. For an excellent discussion of the relationships between liberalism and democracy, see Amy Gutmann, "How Liberal Is Democracy?" in Douglas MacLean and Claudia Mills, eds., Liberalism Reconsidered (Totowa, NJ: Rowman \& Allanheld, 1983).

Don Herzog is Assistant Professor of Political Science at the University of Michigan. He is the author of Without Foundations: Justification in Political Theory (Cornell University Press, 1985), and is now working on a critique of consent theory. 